\title{
KONSEP CINTA DALAM NOVEL AL-LAUN AL-ÃKHAR KARYA IHSAN ABDUL QUDDŨS (Kajian Strukturalisme Genetik Lucien Goldmann)
}

\author{
Imas Fatimah Setiawati dan Rohanda
}

UIN Sunan Gunung Djati Bandung

Email: imasfatimahsetia@gmail.com, rohanda@uinsgd.ac.id

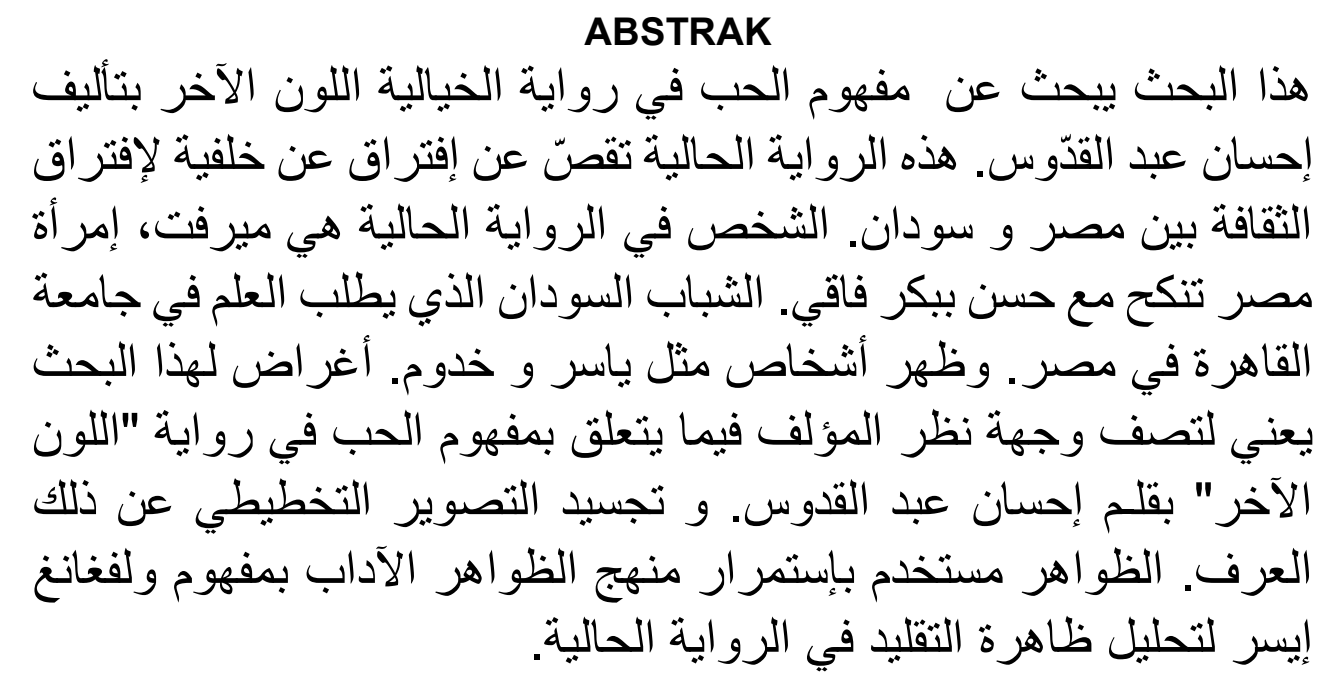

الكلمة الطنانة: الرواية العربية، و النكاح، و عنصر التقليد و تقليد الظاهرة

This research discusses the conception of love in Al-Laun Al-Ãkhar novel by Ihsan Abdul Quds. It tells about the story of separation, which is inspired by cultural differences between Egypt and Sudan. The novel's main character is Mirfat - an Egyptian girl - who married Hasan Babakar Faqia - a Sudanese young man studying at Cairo University, Egypt. This study aims to describe the I. The literary used in this research is the literary genetic structuralism theory to analyze the concepts love found in novels. It reveals that the concepts of love in the novel are about love and personality, love and knowing each other, and love and equality.

Keywords: The concepts of love, Structuralism

\section{PENDAHULUAN}

Karya sastra adalah bagian dari kehidupan manusia yang tidak dapat dipisahkan dari manusia itu sendiri. Orang dapat menggunakan karya sastra sebagai media untuk mengungkapkan perasaan atau pikiran mereka. Wellek 
dan Warren (1989) menyatakan bahwa karya sastra merupakan representasi dari kehidupan. Karya sastra mencerminkan kehidupan. dengan kata lain, kehidupan itu sendiri, dicerminkan atau diimitasi oleh karya sastra dan kita dapat menyatakan bahwa subjek karya sastra ialah berbagai macam pengalaman kehidupan manusia (Wellek, 1989, p. 89).

Kehidupan cinta dialami oleh setiap manusia di dunia, dan memiliki tempat tersendiri dalam kehidupannya, besar kemungkinan bahwa makna cinta, ekspresi cinta, konflik cinta, hingga cerita cinta selalu berbeda bagi setiap orang, tentu saja berbeda pula bagi setiap sastrawan. Sastrawan Arab bernama, Ihsan Abdul Quddũs menulis novel Al-Laun Al-Ãkhar pada tahun 1999, novel ini diterjemahkan kedalam bahasa Indonesia dengan judul Cinta di titik Nol. Kisah cinta ini tidak semata-mata tercipta menjadi sebuah novel, tetapi ada proses historis yang melatar belakanginya, apa yang terjadi sehingga tercipta menjadi novel tersebut.

Untuk dapat menemukan konsepsi cinta yang dimaksud oleh pengarang salah satu pisau yang bisa digunakan adalah strukturalisme genetik. Strukturalisme genetik adalah analisis struktur dengan memberikan perhatian terhadap asal-usul karya, jadi selain menganisis karya sastra, strukturalisme genetik pun mempertimbangan kehidupan pengarang yang melatarbelakangi penulisan novel tersebut.

\section{LANDASAN TEORITIS DAN METODE}

Secara definitif strukturalisme genetik adalah analisis struktur dengan memeberikan perhatian terhadap asal-usul karya. Secara ringkas berarti bahwa strukturalisme genetik sekaligus memberikan perhatian terhadap analitik intrinsik dan ekstrinsik. Menurut Godlman terdapat enam konsep dasar yang membangun teori strukturalisme genetik, yaitu fakta kemanusiaan, subjek kolektif, strukturasi, pandangan dunia, pemahaman dan penjelasan (Faruk, 2016, p. 56). Dengan demikian, strukturalisme genetik memandang karya sastra dari dua sudut, yaitu intrinsik dan ekstrinsik. Studi 
diawali dari kajian unsur intrinsik (kesatuan dan koherensinya) sebagai data dasarnya. Selanjutnya, penelitian akan menghubungkan berbagai unsur dengan realitas masyarakatnya.

Fakta kemanusiaan adalah segala hasil aktivitas atau perilaku manusia, fakta ini merupakan landasan ontologies dari strukturalisme genetik. Fakta-fakta itu dapat berwujud aktivitas sosial, aktivitas politik, atau kreasi kultural, Goldman berpandangan bahwa semua fakta kemanusiaan merupakan struktur yang berarti. Karena itu pemahaman mengenai fakta kemanusiaan harus mempertimbangkan struktur dan artinya yang terikat oleh satu tujuan yang dimaksud. Resepsi pernikahan misalnya, ditujukan untuk memperoleh persetujuan sosial dari kedua pihak masyarakat untuk melakukan sebuah hubungan antara dua individu dan hubungan dua keluarga. Untuk tujuan itulah rangkaian acara resepsi disusun dan saling berhubungan (Faruk, 2016, p. 57).

Salah satu fakta kemanusiaan yang sering diangkat dalam sebuah karya sastra sepanjang sejarah adalah segala aktivitas mencintai, hingga menjadi berbagai macam makna cinta, dan berbagai kisah cinta. Tidak hanya menjadi inspirasi bagi sastrawan. Fakta kemanusiaan cinta tiada habisnya untuk dibahas dalam kajian apapun, baik itu antropologi, psikologi, sufisme, kemudian tidak heran salah satu ilmuan psikologi humanistik Erich Fromm, sering memaparkan konsep cinta dalam beberapa bukunya, bahkan menulis buku khusus mengenai cinta yaitu The Art of Loving beliau lebih jelas mendefinisikan cinta ini dalam empat unsur utama cinta, yaitu Perhatian, Pengasuhan (Care), Tanggung Jawab (Responsibility), Perhatian, Hormat (Respect) dan Pengetahuan, Pengenalan (Knowledge) (Fromm, 1987, p. 35).

Metode yang digunakan dalam penelitian ini adalah metode deskriptif analitik yakni metode penelitian yang bertujuan memberikan gambaran tentang Konsep Cinta pada novel Al-Laun Al-Ãkhar karya Ihsan Abdul Quddũs yang diteliti secara objektif. Dengan menggunakan metode ini 
peneliti mencoba menganalisa konsep cinta yang dipakai pengarang dalam novel Al-Laun Al-Ãkhar karya Ihsan Abdul Quddũs atau memusatkan perhatian pada masalah-masalah sebagaimana adanya saat penelitian dilaksanakan, hasil penelitian kemudian diolah dan dianalisis dengan mengunakan kajian Struktturalisme Genetik Goldmann. Pendekatan tersebut dipilih karena konsep cinta yang terdapat dalam karya sastra merupakan salah satu Fakta kemanusiaan yang bisa diurai dengan menggunakan Srukturalisme genetik. Dan dalam pengumpulan data, peneliti menggunakan teknik studi pustaka, yaitu mengumpulkan bahan-bahan acuan. Kemudian setelah data terkumpul, selanjutnya dilakukan analisis dengan menggunakan pendekatan Strukturalisme Genetik Lucien Goldmann. Pada prinsipnya peneliti ingin menganalisis Konsep Cinta dalam novel Al-Laun Al-Ãkhar yang dilakukan dengan cara menganalisa Struktur Novel dan Struktur sosial novel yang digambarkan dalam novel tersebut kemudian diuraikan dalam bentuk deskriptif.

\section{HASIL DAN PEMBAHASAN}

Di dalam novel ini banyak sekali membicarakan tentang relasi cinta, atau hubungan yang terjadi diantara tokoh-tokoh, bahkan yang terjadi antara tokoh utama antagonis dan protagonis pun merupakan hubungan Suami istri, atau dalam pembahasan cinta kita sebut sebagai cinta erotik atau cinta lawan jenis. Di dalam konsep struktur sosial mutlak adanya hubungan atau relasi di antara unsur-unsur sosial, manusia sebagai unsur utama dalam struktur sosial ini terlihat juga dalam struktur novel Al-laun Al-Ãkhar, hubungan yang terjadi antara tokoh-tokoh ini penulis namakan sebagai cinta, berikut beberapa tokoh dan jenis-jenis hubungan yang terjadi di antara tokoh-tokoh dalam novel Al-laun Al-Ãkhar ini.

\section{Cinta Mirfat dan Hasan}

Mirfat dan Hasan adalah tokoh utama dalam novel ini, maka relasi diantara mereka lah yang diceritakan dalam novel ini secara keseluruhan, 
Mirfat dan Hasan adalah sepasang kekasih yang berhasil melanjutkan hubungannnya ke jenjang pernikahan dan menjadi suami istri. Peneliti melihat bahwa Mirfat sangat mencintai Hasan, begitupun sebaliknya Hasan pun sangat mencintai Mirfat.

وقالت ساهمة كأنها تحادث نفسها: "إن حبكهو مصيرى ـ ومنذ التقينا ونحن

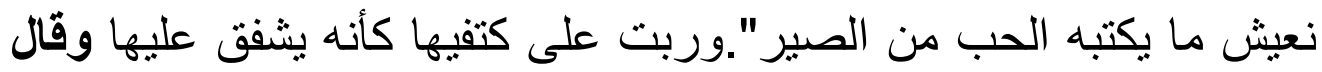
فى صوث حنون :"إننا تعيش الحب مهما كان الصير. نامى. تصبحى على ملى خير"

"cintamu adalah nasibku, sejak kita bertemu dan hidup bersama, apa yang ditetapkan cinta adalah nasibku" gumam Mirfat, seperti bicara dengan dirinya sendiri. Hasan memeluk Mirfat, merasa kasihan. "kita hidup dengan cinta walau bagaimanapun permainan nasib. Tidurlah sampai pagi nanti" kata Hasan penuh cinta (Quddũs, 1999, p. 55).

Untuk sekedar mengungkapkan relasi antara Mirfat dan Hasan benar bahwa mereka saling mencintai, sebagai lawan jenis, atau Fromm menyebutnya dengan jenis cinta erotik, yaitu cinta diantara satu orang lakilaki dan satu perempuan secara eksklusif. Tetapi untuk mengukur apakah mereka benar-benar dalam "cinta", itu merupakan pembahasan yang panjang. Novel ini justru menceritakan kegagalan relasi cinta di antara mereka, ditemukan beberapa data yag menunjukan kelemahan cinta mereka, diukur dari aspek perhatian, tanggung jawab, respek dan pengenalan diantara mereka.

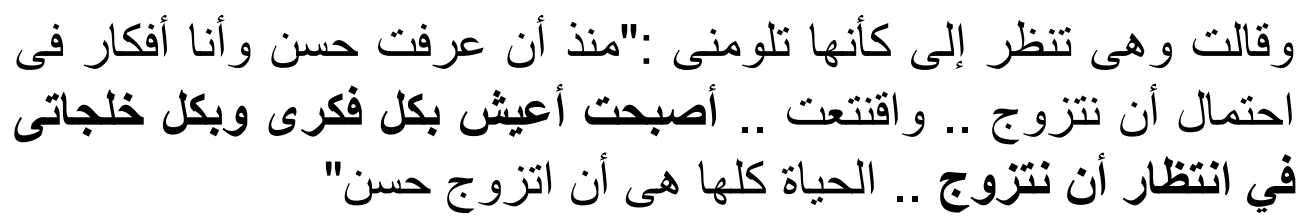

Mirfat berkata seakan mengancamku "Sejak mengenal Hasan aku sudah memikirkan kemungkinan untuk menikah aku telah yakin segala pikiran dan obsesiku sekarang ini adalah menunggu pernikahan kami. Kehidupanku adalah ketika aku menikah dengan Hasan" (Quddũs, 1999, p. 27). 
Data di atas menunjukan tekad Mirfat untuk menikah dengan Hasan, cintanya terhadap Hasan, membuat seluruh pikiran dan perhatiannya hanya tertuju pada pernikahanya dengan Hasan apapun yang terjadi. Tindakan Mirfat ini merupakan aspek cinta perhatian (care), Diceritakan bahwa saking pikiran dan perhatiannya tertuju pada pernikahan Mirfat tidak mempertimbangkan kuliahnya yang hampir selesai, tidak juga mempertimbangkan apakah akan tinggal di Kairo atau di Khurtum, bahkan meskipun orang tuanya tidak merestui, Mirfat memiliki potensi untuk melakukan pernikahan itu kapan saja.Dalam care, seseorang akan berusaha melakukan pemenuhan kebutuhan demi seseuatu yang ia cintai (Fromm, 1983: 36) Mirfat menunjukan tindakan tersebut meskipun efeknya adalah mereka Mirfat dan Hasan tidak mempertimbangkan banyak hal yang cukup penting, hal ini karena aspek perhatian ini tidak disertai dengan pengenalan dan sikap tanggung jawab yang cukup.

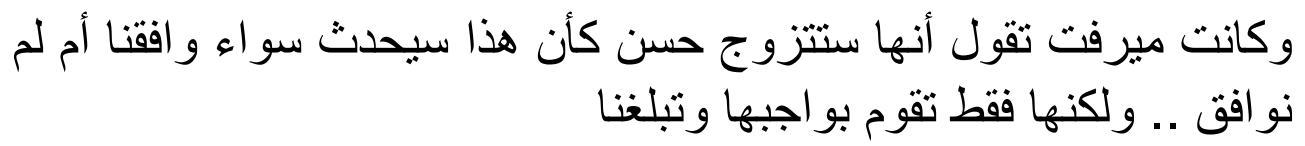

Ketika Mirfat mengatakan ingin menikah dengan Hasan, sepertinya hal itu pasti terjadi baik kami setuju atau tidak. la hanya melakukan kewajibannya dan memberi tahu kami (Quddũs, 1999, p. 26).

\section{Cinta Paman kepada Mirfat}

Novel ini secara keseluruhan memang menceritakan tentang kisah cinta antara Mirfat dan Hasan tetapi karena mengambil sudut pandang dari pamannya sering kali ditegaskan bahwa tokoh "aku" atau pamannya Mirfat ini sangat mengenal Mirfat dan mereka sangat dekat bahkan lebih dekat dari pada dengan orang tuanya sendiri

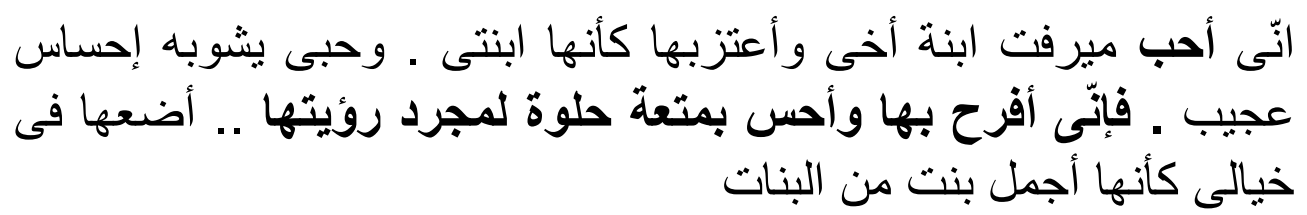


Aku menyukai dan bangga pada keponakanku, Mirfat layaknya anak sendiri. Cintaku terhadap Mirfat diikuti perasaan takjub. Aku gembira dan merasa senang dengan melihatnya. Dalam bayanganku, ia adalah wanita tercantik di dunia (Quddũs, 1999, p. 7).

Dari data di atas terlihat bahwa paman begitu respek dan sangat memperhatikan Mirfat, diksi cintaku pun sangat jelas menunjukan bahwa Paman mencintai Mirfat, mencintai dalam artian menganggapnya seperti anak sendiri, artinya paman memperlakukan Mirfat seperti ayah kepada anaknya, yaitu merawatnya, memperhatikannya, jadi teman curahan hatinya, bahkan paman ini selalu memberikan solusi yang penting bagi Mirfat dan cukup berpengaruh dalam alur novel ini

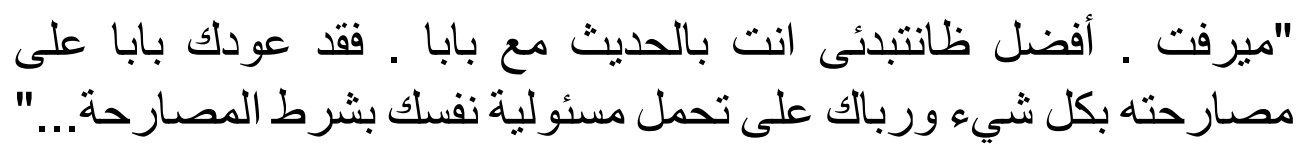

"Mirfat sebaiknya kamu yang memulai bicara dengan ayahmu, ayahmu telah bisa mendengar keterusteranganmu dalam segala hal ia mendidikmu agar bertanggungjawab terhadap diri sendiri asalkan terus terang..." (Quddũs, 1999, p. 29).

Data di atas adalah perkataan paman kepada Mirfat saat Mirfat meminta paman untuk membujuk Ayahnya agar Ayahnya menyetujui hubungannya dengan Hasan, paman ini cukup bijak, karena memberikan solusi yang objektif, tidak berpihak pada Medhat (Ayah mirfat) ataupun pada Mirfat, dia menyarankan untuk Mirfat sendiri yang bicara langsung kepada Ayahnya, karena paman ini pun mengenal mereka berdua. Walaupun kemudian setelah Mirfat berterus terang mengutarakan maksudnya untuk meminta restu, Ayah, Ibu dan keluarganya marah, tidak sedikitpun memberikan restu kepada Mirfat. Dan paman ini tidak diam begitu saja, paman merasa bertanggung jawab untuk menyelesaikan masalah yang tejadi pada keluarga Mirfat, walaupun tidak berhasil meredakan amarah dan suasana yang mencekam, Paman berhasil mengutarakan sarannya kepada Medhat yaitu memberikan restu kepada Mirfat sebagai solusi terbaik ketika itu 
Data di atas menunjukan paman ini sangat bertanggungjawab terhadap apa yang terjadi kepada Mirfat, dan mempertimbangakn apa yang terjadi jika mengambil sikap tergesa-gesa dan tidak berhati-hati. Relasi antara paman dan Mirfat ini termasuk jenis cinta keibuan (orang tua), yaitu kelimpahan kasih sayang dari seseorang yang bijak dan berdaya kepada yang lemah dan membutuhkan. Dengan demikian bentuk pengertian, tanggung jawab, perhatian dan pengenalan pun layaknya seperti orang tua kepada anaknya.

\section{Alur Kisah Cinta}

Selain tokoh-tokoh dan relasi yang terjadi diantara mereka alur juga merupakan unsur penting dalam novel untuk menangkap konsep cinta di dalamnya. Alur novel ini, di awali dengan popularitas Mirfat di Unversitas Kairo dan pertemuannya dengan beberapa pria, yang pada akhirnya bertemu dengan Hasan Babakar Fakki, kemudian mereka memutuskan untuk menikah, tetapi harus menghadapi orang tua dan keluarga Mirfat yang tidak menyetujui hubungan mereka karena latar belakang Hasan sebagai orang Sudan, tetapi karena pembelaan yang cukup rasional dari pamannya akhirnya orang tua Mirfat merestui. Setelah pernikahan, mereka memutuskan untuk tinggal di Sudan namun kehidupan dan pernikahan ini tidak sesuai harapan Mirfat, Hasan terasa berbeda dari biasanya dan keluarga Hasan pun tidak terlalu menyambutnya. Setelah melangsungkan pernikahan di Mesir, mereka harus melakukan upacara pernikahan di Sudan dengan berbagai tradisinya, Mirfat kesulitan mengikuti tradisi dan menyesuaikan diri dengan adat Sudan, Mirfat juga enggan mengikuti salah satu tradisi Sudan yang paling menyakitkan yaitu Khitan, akhirnya Mirfat memutuskan untuk pulang ke Mesir

\section{Latar}


Dari alur yang diuraikan diatas, penulis melihat bahwa pengambilan latar tempat dalam novel ini cukup penting. Novel ini mengambil setting tempat Kairo Mesir sebagai latar belakang Mirfat dan Khurtum di Sudan sebagai latar belakang Hasan, kedua latar ini memiliki perbedaan yang sangat kentara. Kairo adalah ibu kota metropolitan Mesir sedangkan Sudan termasuk negara yang tertinggal di timur tengah yang perkembangan ekonomi dan budayanya sangat jauh dibandingkan Mesir. Perbedaan tempat inilah yang melatarbelakangi konflik pertama dimulai yaitu antara Mirfat dan orang tua, ketidaksetujuan mereka atas hubungan Mirfat dan Hasan dikarenakan perbedaan yang terlalu kontras antara watak dan tradisi Kairo dan Khurtum, kemudian perbedaan ini pula yang melatarbelakangi konflik utama novel ini yaitu antara Mirfat dan Hasan, berikut data yang menunjukan latar tempat yang diambil oleh pengarang:

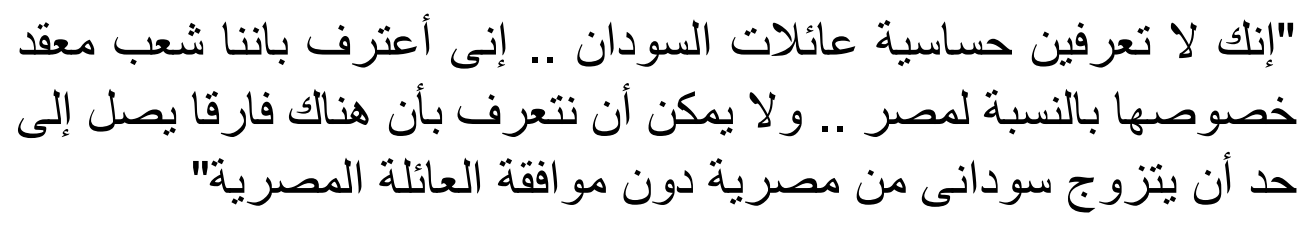

"Kamu tidak tahu sensitivitas keluarga di Sudan, aku mengakui kalau kami adalah masyarakat yang ruwet, khususnya dibandingkan masyarakat mesir akan tetapi, kami tidak mungkin mengakui bahwa di sana terdapat perbedaan sampai-sampai seorang Sudan menikah dengan seorang Mesir tanpa mendapat persetujuan keluarga Mesir" (Quddũs, 1999, p. 35).

\section{Tema Cinta dan Tema-tema yang Menopang}

Untuk menangkap tema dalam sebuah novel, Nurgiyantoro (2002) mengatakan bahwa haruslah dengan cara memahami cerita, mencari kejelasan ide-ide perwatakan, peristiwa-peristiwa konflik dan latar. Para tokoh biasanya dibebani tugas membawakan tema, yang kemudian para tokoh ini membawakan konflik, konflik merupakan salah satu unsur pokok dalam pengemabangan ide cerita dan plot, pada umumnya erat kaitannya dengan tema (Nurgiyantoro, 2002, p. 85). 
a) Tema Cinta

Tokoh dan penokohannya, alur dan konfliknya serta latar telah dibahas panjang lebar sebelumnya. Dari pembahasan sebelumnya, penulis menyimpulkan bahwa tema utama atau tema mayor dalam novel Al-laun AlÃkhar ini adalah tema cinta, sedangkan yang menjadi tema minor atau tema yang mendukung tema cinta dalam novel ini yaitu tema perempuan dalam tradisi dan tema rasisme.

b) Tema Perempuan dalam Tradisi

Tema perempuan dalam tradisi ini menjadi tema minor karena dibahas dan ceritakan di dalam novel ini cukup sering dan posisinya tetap hanya sebagai penopang tema cinta. Tema perempuan yang dimaksud disini adalah wacana kesetaraan antara laki-laki dan perempuan, atau relasi gender, dalam penelitian ini adalah relasi gender dalam tradisi Mesir dan relasi gender dalam tradisi Sudan dalam kisaran waktu antara 1950-1990 berdasarkan masa produktifitas pengarang, Ihsan.

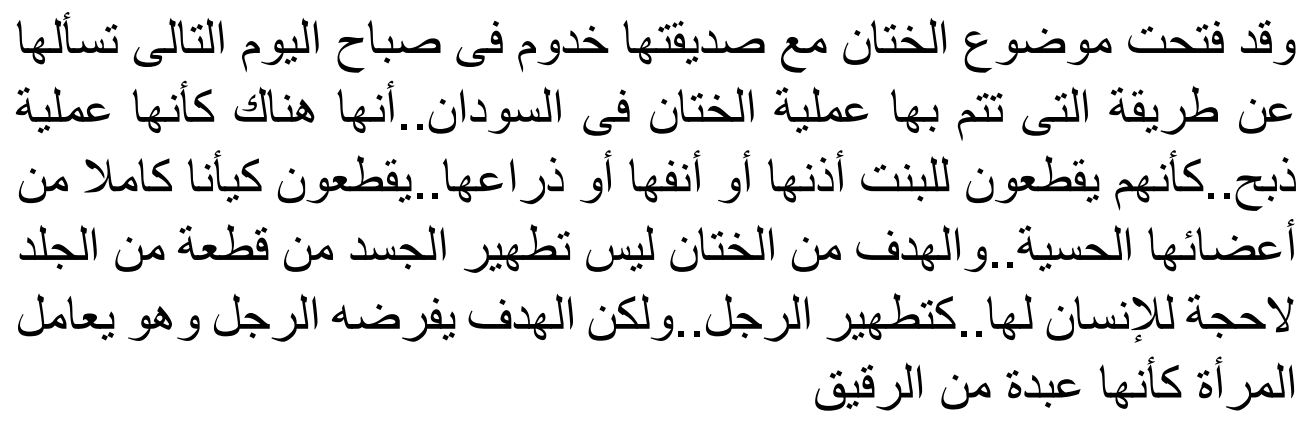

Pada pagi hari berikutnya, Mirfat membahas masalah khitan ini dengan Khadum. la bertanya tentang cara-cara khitan di Sudan. Menurut Khadum, khitan di Sudan seperti acara pembunuhan. Mereka layaknya memotong telinga, hidung, atau tangan si wanita. Mereka memotong organ tubuh paling sensitif bagi wanita secara sempurna. Tujuan khitan pada wanita bukanlah menyucikan tubuh dari sepotong kulit yang tidak dibutuhkan manusia, seperti halnya pada lelaki. Akan tetapi, tujuannya telah ditetapkan kaum pria, yaitu untuk memperlakukan wanita seakan budak mereka (Quddũs, 1999, p. 51). 
Praktik khitan perempuan atau Female Genital Mutilation ini sudah lama dan sudah banyak mendapatkan perlawanan, tetapi dari novel yang ditulis Ihsan ini, pada tahun 1999 praktik in masih dilakukan sebagai tradisi turun temurun yang belum terlihat adanya perubahan, hal ini karena praktik khitan ini tidak hanya dipandang sebagai tradisi tetapi kewajiban. Apabila perempuan tidak melakukan khitan maka akan dianggap tabu, kotor, dan penghinaan bagi keluarga atau suami mereka. Berikut kutipan informasi dari (Landinfo, 2009, p. 6) yang menunjukan bahwa bahkan tahun 2018 masih ada praktik ini

c) Tema Rasisme

Tidak hanya tema perempuan dalam tradisi, tema rasisme juga menopang tema cinta dalam novel ini. Novel ini diberi judul Al-laun Al-Ãkhar, bukan tanpa alasan, peneliti memprediksi, hal ini berkaitan dengan perbedaan warna kulit di antara tokoh utama yaitu, Mirfat dan Hasan. Mirfat memiliki warna kulit putih albino dan berambut blonde, sedangkan Hasan berkulit Hitam dan rambut hitam pekat perbedaan warna kulit mereka ditampilkan dalam sampul novel ini. Selain itu, Perbedaan ras dan warna kulit ini juga sering dibahas oleh Paman yaitu sudut pandang novel ini sebagai "aku".

وكان ما لاحظته وأنا أحاول اكثاف ذوق ميرفت فى اختيار أصدقائها أن

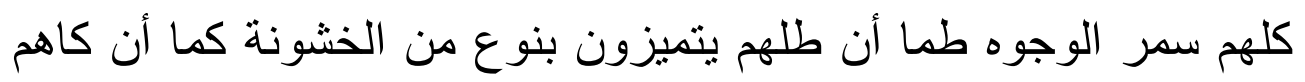
من الطبقة العادية

Dari hasil pegamatanku ketika berusaha mengetahui selera Mirfat dalam memilih teman prianya, mereka semua berkulit cokelat dan kasar, serta dari golongan bawah.(Quddũs, 1999: 10)

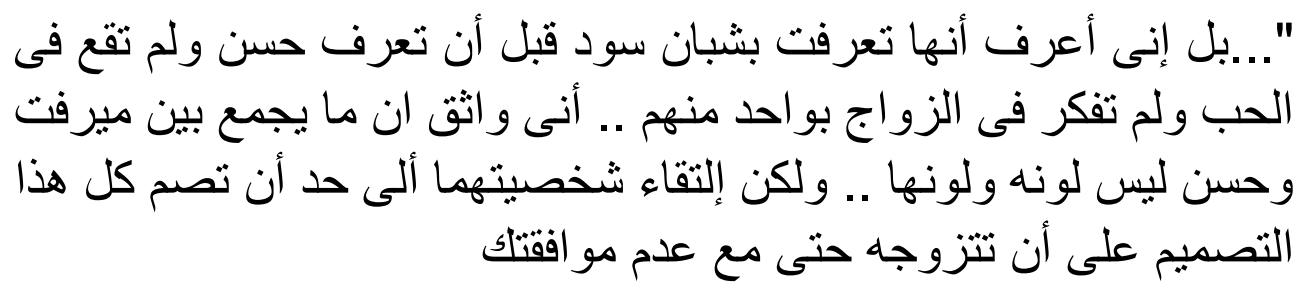


“... Bahkan aku tahu kalau dia berkenalan dengan pemuda hitam sebelum mengenal Hasan, namun dia tidak jatuh hati dan tidak berpikir tentang pernikahan dengan salah seorangpun dari mereka. Aku yakin, yang mempertemukan Mirfat dan Hasan bukanlah warna kuit mereka, melainkan kepribadian mereka, sehingga keduanya bersikeras untuk menikah meskipun tidak mendapatkan persetujuanmu...” (Quddũs, 1999, p. 32).

\section{Konsep Cinta dalam Pandangan Dunia Pengarang}

\section{Cinta dan Kecocokan Pribadi}

Penulis melihat bahwa cinta yang diceritakan novel ini bukan hanya tentang perasaan, tapi aspek-aspek lain yang lebih bisa dan cukup dapat dijelaskan secara panjang dan rasional. Data dibawah adalah satu contoh yang berkaitan dengan konsep cinta yang berkaitan dengan kepribadian antar seseorang.

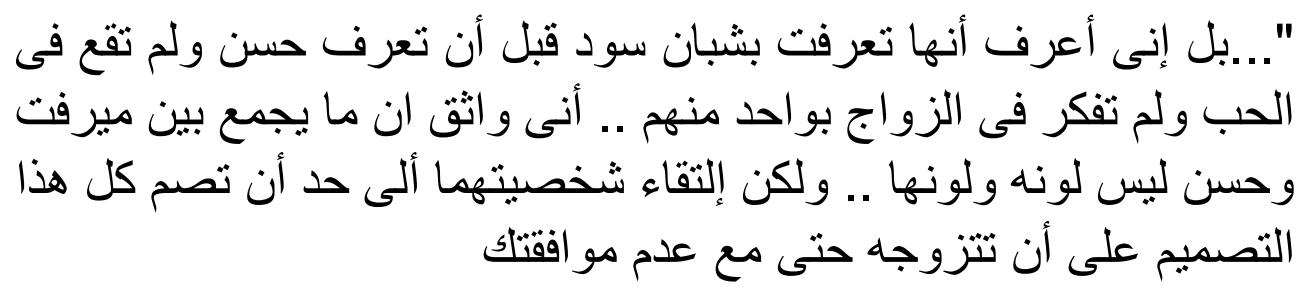

“... Bahkan aku tahu kalau dia berkenalan dengan pemuda hitam sebelum mengenal Hasan, namun dia tidak jatuh hati dan tidak berpikir tentang pernikahan dengan salah seorangpun dari mereka. Aku yakin, yang mempertemukan Mirfat dan Hasan bukanlah warna kuit mereka, melainkan kepribadian mereka, sehingga keduanya bersikeras untuk menikah meskipun tidak mendapatkan persetujuanmu..." (Quddũs, 1999, p. 32).

Dari data diatas selain dapat menguatkan bahwa novel ini menyinggung rasisme, data tersebut juga menunjukan konsep cinta yang disampaikan pengarang dalam novel ini yaitu bahwa yang menyatukan seseorang dengan yang lainnya dalam cinta bukanlah warna kulit atau fisik lainnya tetapi kepribadian, stetmen ini juga berulang kali dilontarkan oleh tokoh paman (aku) ini diantaranya:

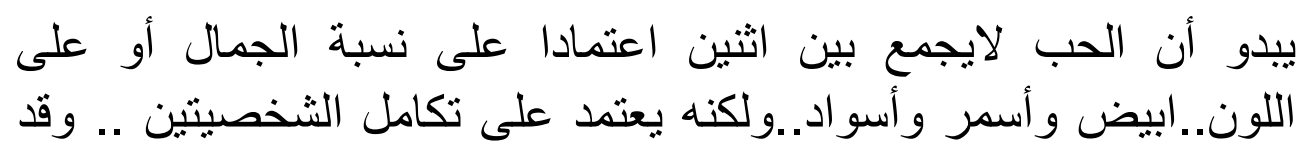




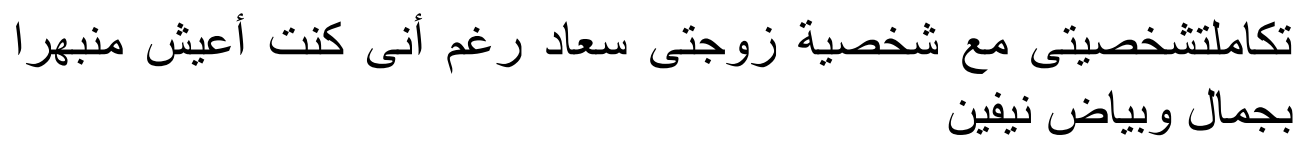

Sepertinya, cinta tidak mempertemukan dua orang manusia atas dasar kecantikan atau warna putih, cokelat, dan hitam. Cinta mempertemukan dua orang manusia atas dasar kecocokan dua pribadi. Pribadiku cocok dengan pribadi istriku Suad, meskipun aku silau dengan kecantikan dan putihnya Nevin (Quddũs, 1999, p. 8).

Upaya untuk menyatukan pribadi ini telah dilakukan oleh Mirfat dan Hasan, dengan berusaha saling mengenal, kemudian perjuangan mereka untuk menikah, tetapi tampaknya novel ini ingin menunjukan kegagalan mereka dalam menyatukan pribadi, seperti yang tergambarkan dalam data berikut:

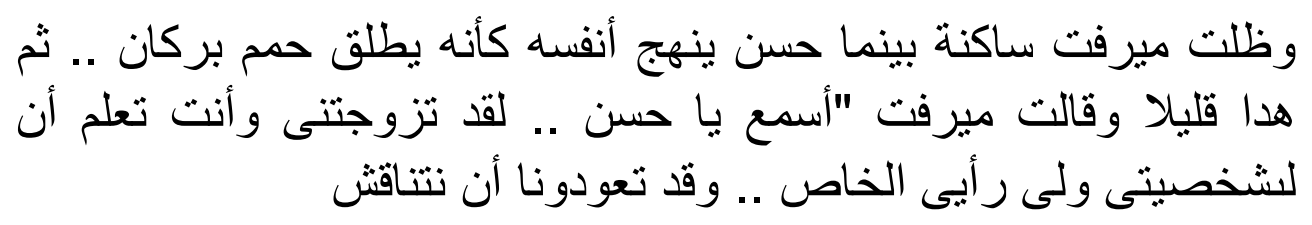

Mirfat hanya diam, sementara itu, napas Hasan memburu seperti ingin melepaskan lahar panas sebentar kemudian, napasnya sudah agak tenang "dengar hasan" ujar Mirfat "ketika menikahiku kamu tahu kalau aku memilkiki kepribadian dan pendapat sendiri. Kita sudah membicarakan segala sesuatunya.." (Quddũs, 1999, p. 64).

\section{Cinta dan Ta'aruf}

Selain gagasan tentang bahwa Cinta disatukan dengan kecocokan pribadi, pengarang tampaknya ingin menunjukan bahwa kecocokan antar pribadi ini hanya bisa terjadi apabila sudah saling mengenal, seperti yang ungkapkan oleh Fromm bahwa mana mungkin seseorang bisa saling menerima apa adanya, jika tidak mengenal satu sama lain keadaannya.

Novel ini mengisahkan tentang dua orang yang tiba-tiba saling jatuh cinta, berhasrat buru-buru mengikatnya dengan pernikahan, walaupun orang tua dari kedua pihak tidak saling merestui, tanpa perjalanan dan pengenalan yang cukup, pernikahan itu berlangsung begitu cepat dan terkesan 
memakskan. Ketidaksalingmengenalan ini tergambarkan dengan pengalaman Mirfat saat pertama kali ke Sudan, Mirfat heran dengan sikap Hasan dan mengalami Shock Culture yang cukup menekan, ini menandakan Mirfat tidak mengenal Hasan dengan baik.

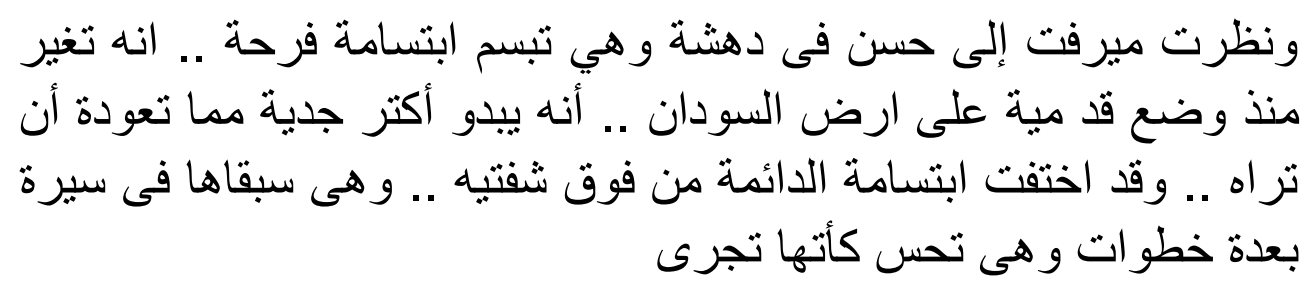

Mirfat tersenyum sumringah tetapi melihat Hasan ia heran Hasan kelihatan berubah sejak menampakan kakinya di tanah Sudan. la terkesan lebih serius daripada biasanya. Senyuman yang selalu mengembang di bibirnya juga telah sirna. Hasan bejalan mendahului Mirfat dalam jarak beberapa langkah, Mirfat seakan berlari di belakangnya (Quddũs, 1999, p. 40).

seseorang yang benar-benar saling mencintai seharusnya saling mengenal sebaik mungkin, mulai dari latar belakang keluarganya, tradisi tempat dimana ia tumbuh, dan kepribadiannya secara mendalam, apalagi untuk seseorang yang akan menjadi kekasih sah, karena itu pernikahan bukanlah hal yang sepele. Mirfat tidak akan shock culture jika ia pernah ke Sudan sebelumnya. Berikut beberapa keheranan dan kekagetan yang dialami mirfat:

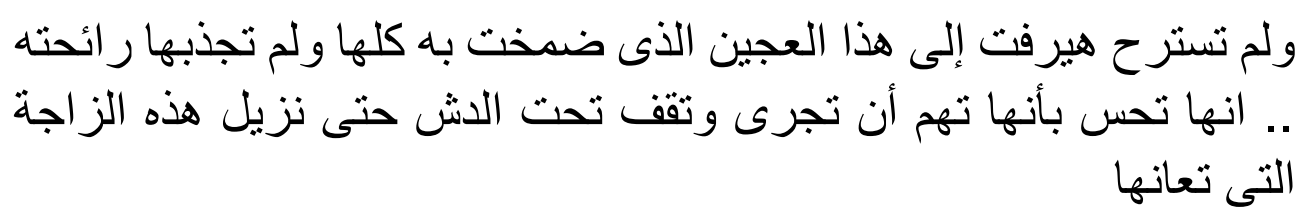

Mirfat tidak senang dengan krim yang melumuri seluruh tubuhnya, baunya menyengat, ia merasa ingin lari dan berdiri di bawah shower untuk menghilangkan krim yang melekat pada tubuhnya (Quddũs, 1999, p. 47).

Mirfat mengalami berbagai pengalaman baru, beberapa terasa menyenangkan seperti memakai Henna, memakai tubb, dan menari ala Sudan, tradisi-tradisi seperti itu seperti hadiah bagi Mirfat, tetapi beberapa 
juga terasa menyesakkan, seperti batasan pergaulan antara perempuan dan laki-laki, atau norma-norma lain yang tidak ada di Kairo

مبرفت تجر أت لحظة وأطلت بوجهها كله من الثباك بحيث يمكن أن ير اها كل الرجال .. كانت تبحث بعينيها عن ابن عمها ياسر حتى تطمئن إلى أنه

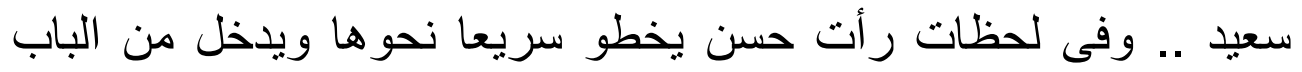

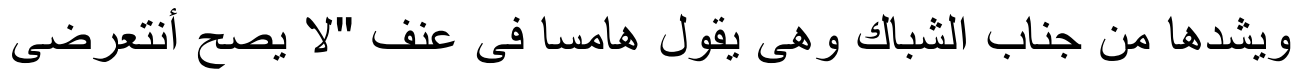

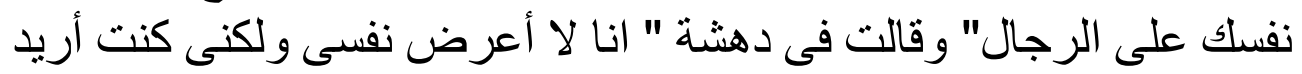

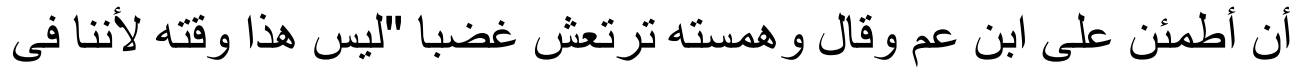
الخرطوم ولسنا فى القاهرة" أن وطن

Mirfat nekat menjulurkan kepalanya di jendela untuk mencari Yasir dan memastikan saudaranya itu juga ikut bahagia. Segera saja ia melihat Hasan melangkah cepat ke arahnya dan masuk dari pintu. Hasan menariknya dari jendela dan berbisik dengan tegas "tidak benar kamu memperlihatkan diri pada kaum lelaki"

"aku tidak memperlihatkan diri, aku hanya ingin melihat anak pamanku"kata Mirfat terkejut

Hasan berbisik dan tampak marah "ini bukan saatnya, kita sedang di Khurtum bukan di Kairo" (Quddũs, 1999, p. 49).

Data diatas tidak seberapa mengagetkannya dibandingkan tradisi yang mengharuskan Mirfat dikhitan dan paksaan untuk hamil, seperti yang telah dibahas sebelumnya di tema perempuan dalam tradisi. Yang paling menyesakkan adalah pertengkaran yang tiada habisnya diantara mereka, hal ini bukan hanya karena Mirfat tidak mengenal Hasan dan tradisi Sudannya, tetapi Hasan pun tidak mengenal Mirfat dengan baik, padahal ia sudah lama tinggal di Kairo, Hasan tidak benar-benar mengerti bagaimana perasaan Mirfat sebagai orang Kairo hidup di Khurtum, Hasan pun selalu melupakan fakta bahwa gadis Kairo lebih membutuhkan kebebasan dan sangat melindungi kepribadiannya, dan bagi Mirfat, Khitan adalah membunuh kepribadian dan hamil harus berdasarkan perencanaan. Hasan terlalu fokus bagaimana ia menjadi pria Sudan lagi setelah lama tinggal di Kairo, hingga tidak memperhitungkan perasaan Mirfat 


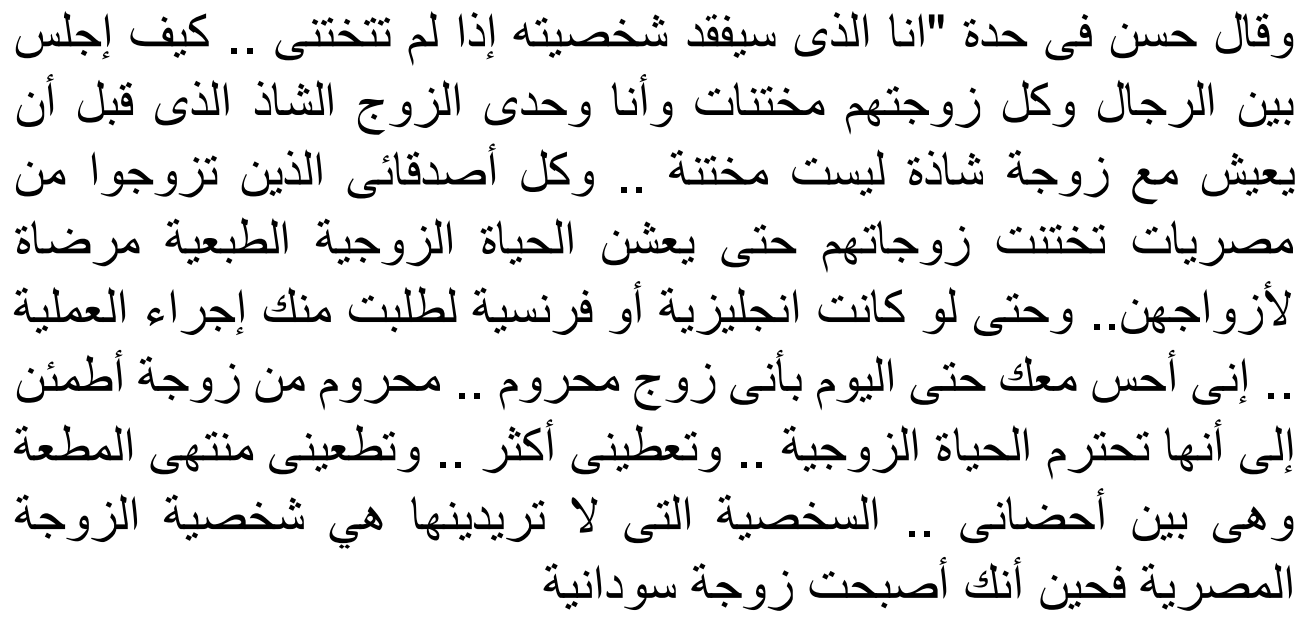

Hasan berkata dengan tegas "akulah yang akan kehilangan kepribadian jika kamu tidak dikhitan, bagaimana aku bisa duduk bersama kaum lelaki yang istri-istri mereka sudah dikhitan, sementara aku adalah suami sesat yang menerima hidup dengan seorang istri sesat karena tidak melakukan khitan? sahabat-sahabatku yang menikah dengan para wanita mesir juga telah mengkhitan istri-istri mereka sehingga bisa menjalani kehidupan keluarga secara normal, dan dengan begitu, para istri tersebut telah memuaskan suami-suaminya. Bahkan jika kamu seorang wanita inggris ataupun prancis, aku akan tetap memintamu untuk dikhitan. Sampai hari ini aku merasa sebaga seorang suami yang bernasib buruk karena tidak memilki istri yang aku yakin bisa menghormati kehidupan keluarga. Istri yang memberiku lebih banyak ... memberiku puncak kenikmatan ketika ia berada dalam pelukanku. Kepribadia yang kamu inginkan adalah kepribadian istri mesir, sedangkan kamu telah menjadi seorang istri sudan" (Quddũs, 1999, p. 54).

\section{Cinta dan Kesetaraan}

Novel ini sangat jelas mengangkat isu Kesetaraan ras dan Gender. Novel ini ingin mengangkat kedua isu tersebut sekaligus dan sangat bersamaan yaitu dengan kisah cinta antara dua orang laki-laki dan perempuan yang berbeda ras yaitu kulit putih dan kulit hitam. Data berikut adalah salah satu sikap Mirfat menghadapi salah satu tradisi khurtum yang bertentangan dengan prinsip kesetaraan yang sudah mendarah daging dihidupnya. 
وقررت ميرفت ألا تعرض نفسها لعملية الختان مهما ألح حسن .. ومهم بلغ

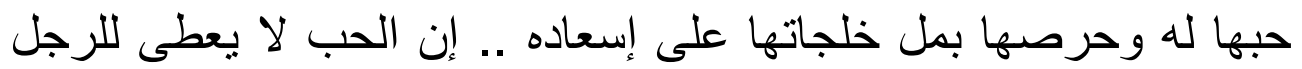

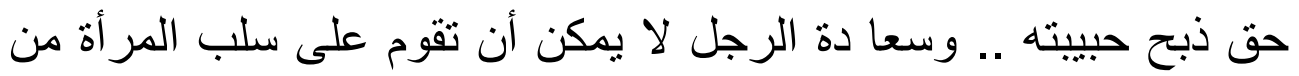

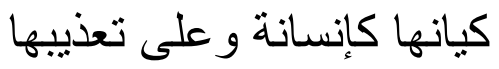

Mirfat memutuskan untuk tidak membahayakan dirinya sendiri dengan melakukan Khitan, meski terus didesak dan sebesar apapun cinta serta keinginannya untuk membahagiakan Hasan. Cinta tidak memberi hak kepada lelaki untuk menyembelih kekasihnya, kebahagiaan lelaki tidak mungkin berdiri di atas penyiksaan dan pemasungan eksistensi wanita sebagai wanita (Quddũs, 1999, p. 53).

Data diatas tidak hanya menunjukan keteguhan Mirfat sebagai gadis mesir dengan keputusannya untuk tidak dikhitan, tetapi pandangan Mirfat yang dengan yakin bahwa cinta tidak memberi hak kepada lelaki untuk menindas kekasihnya, tampaknya ini adalah gagasan pengarang mengenai konsep cinta antara laki-laki dan perempuan. Dari beberapa karyanya, beliau sangat jelas menunjukan perhatiannya terhadap isu-isu gender, dan seksualitas. Berikut salah satu ungkapan yang mengkritik salah satu norma Sudan yang tidak mengamini kesetaraan gender

وقالت ميرفت وهى تضحك ساخرة :"إن الرجل أذا أراد أن يحمى ألمر أة

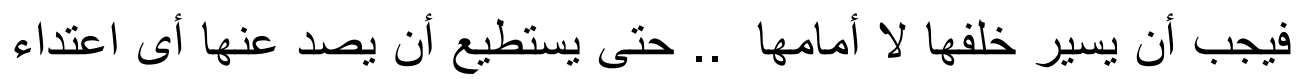
يأتيها من الخلف وفي الوقت نفسه يرى الإعتداء الذى يقبل عليها من الأمام فيهرع ألى صده عنها .. أنكم تذكر وننى بالأغوات الذين كانو يسيرون أيام

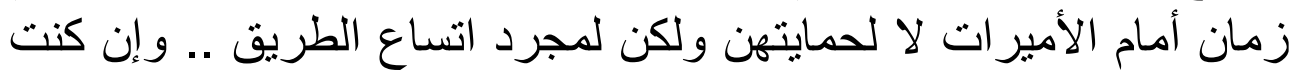

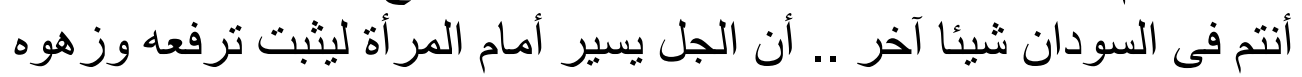

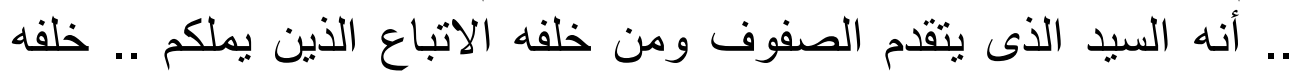

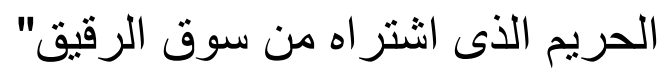

Mirfat hanya tertawa mengejek "kalau memang laki-lakihendak melindungi wanita, seharusnya pria berjalan di belakangnya, bukan di depannya, sehingga bisa menghadang segala macam ancaman yang datang dari belakan, sekaligus bisa melihat adanya ancaman di depan untuk segera berlari menghadangnya. Kalian mengingatkanku pada pasukan permaisuri, 
tidak untuk melindungi mereka, tetapi untuk sebatas membuka jalan, akan tetapi, kalian di Sudan lain lagi, pria di sini berjalan di depan wanita untuk membuktikan ketinggian dan keluhurannya, hal ini untuk membuktikan kalau dialah tuan yang memimpin barisan, sementara di belakangnya adalah para pengikut, budak-budak yang dia miliki dan wanita-wanita yang dibeli dari pasar budak" (Quddũs, 1999, p. 61).

Tidak hanya kesetaraan gender yang diungkapkan dalam kisah cinta ini, tetapi juga kesetraan ras, dan kelas. Berikut data yang menunjukan sikap kesetaraan Mirfat dalam upayanya memilih dan menentukan kekasih hidupnya

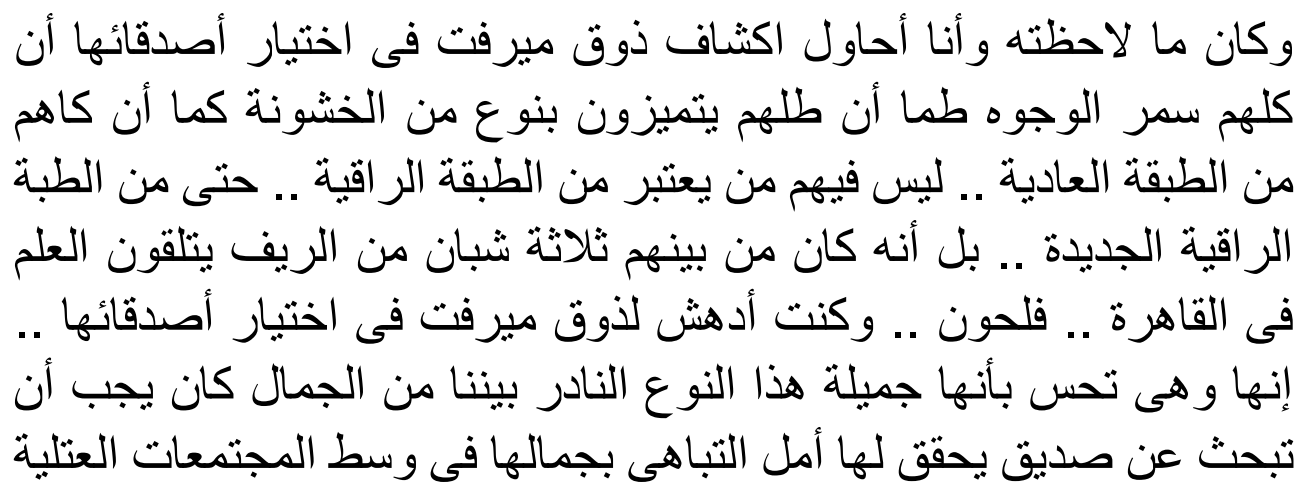

Dari hasil pegamatanku ketika berusaha mengetahui selera Mirfat dalam memilih teman prianya, mereka semua berkulit cokelat dan kasar, serta dari golongan bawah, tidak ada seorangpun yang berasal dari golongan kaya, bahkan tidak juga golongan kaya baru, malah, tiga diantaranya adalah pemuda kampung yang tengah belajar di Kairo - para petani. Aku heran dengan selera Mirfat dalam memilih teman-teman prianya, sementara ia merasa memiliki kecantikan semacam ini yanglangka di kalangan kami. Seharusnya Mirfat mencari teman pria yang mampu mewujudkan keinginan untuk membanggakan kecantikan di tengah-tengah masyarakat kelas saya. (Quddũs, 1999, p. 11).

Data di atas adalah unkapan paman (aku) dalam mengamati keponakannya, paman menganggap bahwa Mirfat berbeda dengan gadis lain, Sikap Mirfat ini menunjukan bahwa dirinya mengukur seseorang bukan berdasarkan warna kulit, ataupun status sosial, baginya semua manusia sama, dan Mirfat merasa nyaman dengan beberapa pria pilihannya karena 
kepribadiannya, seperti yang telah dibahas panjang lebar sebelumnya di poin cinta dan kecocokan pribadi. Seakan inilah yang disuarakan Ihsan dsalam novelnya.

\section{PENUTUP}

Setelah melakukan analisa yang cukup panjang dengan menggunakan pendekatan strukturalisme genetik Lucien Goldmann untuk menjawab rumusan masalah penelitian, penulis dapat mengekstrak beberapa poin sebagai simpulan penelitian sebagai berikut:

1. Tema cinta dalam novel ini merupakan tema utama disamping tematema lain yang menopangnya yaitu tema rasisme dan tema perempuan. Hal ini dibuktikan dengan relasi antar tokoh-tokoh utama dalam novel ini meruapakan relasi cinta. Kemudian, yang mempengaruhi konflik dan alur cerita juga cinta dan pemilihan latar tempat dan waktu juga berdasarkan keputusan antara orang yang saling mencintai. Dari cara-cara inilah sebuah tema dapat ditarik dan bagaimana setiap unsur-unsur ini berhubungan satu sama lain dalam membangun konsepsi cinta.

2. Dari pembacaan novel secara keseluruhan dengan menggunakan pendekatan strkturalisme genetik, dapat ditangkap beberapa poin konsepsi cinta yang digunakan pengarang dalam novelnya

a. Bahwa cinta sebetulnya bukan sekedar tentang perasaan tetapi kecocokan pribadi, kecocokan dalam artian orang yang terlibat dapat saling menerima dan saling melengkapi saling berhubungan tanpa mengganggu jati diri masing-masing

b. Cinta dan kecocokan ini tidak akan dapat terjadi tanpa pengetahuan dan pengenalan yang mendalam satu sama lain, pengenalan ini pun didorong dengan rasa ingin tahu dan care yang kuat terhadap objek cinta, selama pengenalan seperti ini ada, disitu ada cinta, dan jika 
cinta dalam artian mempertahankan hubungan, pengenalan ini seharusnya dilakukan orang-orang terlibat tidak hanya sepihak.

c. Selanjutnya, poin yang paling menonjol dalam novel ini yaitu cinta antara lawan jenis atau cinta erotik ini seharusnya berlandaskan prinsip-prinsip kesetaraan, tidak ada di dalam pikirannya bahwa salah satunya memiliki kedudukan lebih tinggi atau lebih rendah baik berdasarkan rasa atau gender.

\section{A. Saran}

Penelitian pada novel Al-Laun Al-Ãkhar ini menggunakan kajian strukturalisme genetik Lucien Goldmann, namun pada pembahasannya kajian ini juga menggunakan salah satu konsep cinta. Dalam perjalanan proses penelitian upaya mengetahui konsep cinta yang dimaksud pengarang dalam novelnya ini, peneliti menemukan beberapa hal selain konsep cinta. Karena itu peneliti memberikan beberapa saran dan rekomendasi:

1. Karena konsepsi cinta itu sangat luas dan berkaitan dengan berbagai hal dan diharapkan penelitian yang lebih spesifik.

2. direkomendasikan untuk penelitian selanjutnya terhadap novel ini, untuk meneliti khusus mengenai kajian gender atau kajian rasisme. Dan kedua bidang ini bisa menggunakan sosiologi sastra, strukturalisme genetik atau yang lainnya diharapkan upaya yang lebih untuk mendapatkan informasi mengenai biografi dari pengarang yang dimaksud dengan referensi yang terpercaya. Karena informasi ini penting untuk penelitian dan sangat berpengaruh terhadap hasil penelitian.

\section{DAFTAR PUSTAKA}

Faruk. (2016). Pengantar Sosiologi Sastra: dari Strukturalisme Genetik Sampai Post-Modernisme. Yogjakarta: Pustka pelajar.

Fromm, E. (1987). Seni Mencintai (Terj). Jakarta: Bunda karya.

Nurgiyantoro, B. (2002). Teori Pengkajian Fiksi. Yogyakarta: Gadjah Mada University Press. 
Hijai - Journal on Arabic Language and Literature | ISSN: 2621-1343

Quddũs, I. A. (1999). Al-Laun Al-Ãkhar . Kairo: Dar Akhbar al Yaum.

Wellek, R. \&. (1989). Teori Kesusastraan. Jakarta: PT. Gramedia. 